\title{
Correlation between Ascites and Total Lymphocyte Count with Occurrence of Hepatic Encephalopathy in Liver Cirrhosis Patients
}

\section{Hubungan Asites dan Total Lymphocyte Count dengan Kejadian Hepatic Encephalopathy pada Pasien Sirosis Hati}

\author{
Ratna A Pravitasari ${ }^{1}$, Supriono ${ }^{2}$ \\ ${ }^{1}$ Department of Internal Medicine Saiful Anwar General Hospital Malang \\ ${ }^{2}$ Division of Gastroenterohepatology Department of Internal Medicine Saiful Anwar General Hospital Malang
}

\begin{abstract}
Hepatic encephalopathy (HE) is brain dysfunction manifested as a broad spectrum of neuropsychiatric abnormalities caused by hepatic insufficiency or portosystemic shunting due to portal hypertension. Portal hypertension in liver cirrhosis also causes ascites, as the most common clinical manifestation. Further, immune dysfunction, one of which is decreased total lymphocyte count (TLC), happens at liver cirrhosis, which triggers the systemic inflammatory response. This systemic inflammatory response plays a role in HE. Objective of this study is to know the correlation between ascites and TLC with occurence of HE in liver cirrhosis patient. This study was conducted by retrospective cohort design in Saiful Anwar Hospital. Determination of sample amount at this study used total sampling method. Hepatic encephalopathy diagnosis was based on West Haven Criteria. Ascites was determined by physical examination and/or abdominal ultasonography. Total lymphocyte count data was taken from medical record, with complete blood count examination used XS-800i hematology analyzer machine. Data were analyzed using a logistic regression test, with $p<0.05$ was considered significant and Confidence Interval (CI) 95\%. Seventy-eight liver cirrhosis patients were observed using a retrospective cohort method regarding the HE occurrence, and physical examination for ascites and laboratory examination were performed. The statistical analysis result of the correlation between ascites and $\mathrm{HE}$ is significant with an odds ratio of 5.108 and Cl of 1.3619.25. On the other hand, TLC has no significant correlation with the occurrence of HE. Based on this analysis result, it is concluded that ascites has a correlation with HE, but TLC does not.
\end{abstract}

Keywords: Hepatic encephalopathy, ascites, total lymphocyte count.

\begin{abstract}
ABSTRAK
Hepatic encephalopathy (HE) adalah disfungsi otak yang bermanifestasi sebagai spektrum luas abnormalitas neuropsikiatri yang disebabkan oleh insufisiensi hati dan/atau shunting portosystemic akibat hipertensi porta. Hipertensi porta pada sirosis hati juga menyebabkan asites yang merupakan manifestasi tersering. Selain itu, pada sirosis hati terjadi disfungsi imun, salah satunya penurunan total lymphocyte count (TLC), yang memicu respon inflamasi sistemik. Respon inflamasi sistemik tersebut berperan dalam HE. Tujuan dari penelitian ini adalah untuk mengetahui hubungan antara asites dan TLC dengan kejadian HE pada pasien sirosis hati. Penelitian ini menggunakan desain kohort retrospektif yang dilakukan di RS Saiful Anwar. Tujuh puluh delapan pasien sirosis hati diobservasi dengan metode kohort retrospektif mengenai kejadian HE dan dilakukan pemeriksaan fisik untuk asites dan pemeriksaan laboratorium. Penentuan jumlah sampel pada penelitian ini menggunakan metode total sampling method. Diagnosis HE ditegakkan berdasarkan kriteria West Haven. Asites ditentukan dengan pemeriksaan fisik dan/atau ultrasonografi abdomen. Data mengenai total lymphocyte count diambil dari rekam medik, dengan pemeriksaan darah lengkap menggunakan alat XS-800i hematology analyzer. Data dianalisis menggunakan uji regresi logistik, dengan $\mathrm{p}<0.05$ dinilai bermakna dan Confidence Interval (Cl) 95\%. Tujuh puluh delapan pasien sirosis hati diobservasi dengan metode kohort retrospektif mengenai kejadian HE dan dilakukan pemeriksaan fisik untuk asites dan pemeriksaan laboratorium. Hasil analisis statistik hubungan asites dan $\mathrm{HE}$ bermakna secara signifikan dengan odds ratio 5.108 dan $\mathrm{Cl}$ 1.36-19.25. Sementara itu, TLC tidak memiliki hubungan yang signifikan dengan kejadian HE. Berdasarkan hasil analisis tersebut, kami menyimpulkan bahwa asites memiliki hubungan dengan HE tetapi TLC tidak memiliki hubungan dengan HE.
\end{abstract}

Kata Kunci: Hepatic encephalopathy, asites, total lymphocyte count.

Correspondence: Ratna Adelia Pravitasari. Department of Internal Medicine Saiful Anwar General Hospital Malang, Jl. Jaksa Agung Suprapto No. 2 Klojen Malang Tel.081330483656Email:adel.andriyant@gmail.com 


\section{INTRODUCTION}

Hepatic encephalopathy (HE) is a complex spectrum of neuropsychiatric disorders caused by liver disease and metabolic and immunological disorders. The severity degrees vary from minimal (or covert) to overt, coma, and death (1). One of the HE causes is liver cirrhosis, which is associated with increased hospitalization, health costs, and mortality $(2,3)$. The impact of HE does not only affect the patients but also affects all family members, both psychosocial and financial aspects (4).

Hepatic encephalopathy does not occur due to a single causative entity but as a result of a synergistic effect of several mechanisms. The primary mechanism that plays a role in the pathophysiology of $\mathrm{HE}$ is hyperammonemia (5). The increase of blood ammonia in advanced liver disease is a consequence of impaired liver function and shunting of blood flow around the liver due to portal hypertension $(6,7)$. Another mechanism that plays a role is the systemic inflammatory response that modulates the effects of ammonia on the brain. Patients with liver cirrhosis are functionally immunocompromised and prone to developing an infection (1).

Another common manifestation of cirrhosis is ascites. Ascites is the most common cause of liver cirrhosis hospitalization (8). The main factor responsible for developing ascites in liver cirrhosis patients is portal hypertension. In portal hypertension, there are backflow, portosystemic shunting, and impaired clearance of vasodilator substances. The formation of portosystemic collaterals causes systemic vasodilatation and circulatory hyperdynamics, which triggers renal hypoperfusion resulting in activation of the Renin-AngiotensinAldosterone System (RAAS). As a result of RAAS activation, there is an excess fluid, which will then come out directly from the surface of the liver and mesenteric blood vessels into the peritoneal cavity (2-9).

The liver regulates the immune system's homeostasis through two mechanisms, namely immune surveillance and the synthesis of dissolved molecules of effective immune response (10). Cirrhosis and portal hypertension cause dysregulation of immune cell activation and impaired immune response (11). The compromised immune system in liver cirrhosis patients include innate and adaptive immune systems $(12,13)$. In liver cirrhosis, there is a decrease in the number and function of neutrophils, B and T lymphocytes, and NK cells; and increased monocytes but with decreased function (10).

The pathophysiological association between ascites and immune dysfunction with $\mathrm{HE}$ in liver cirrhosis underlies the hypothesis that ascites and immune dysfunction, represented in this study by low total lymphocyte count, will increase the incidence of $\mathrm{HE}$ in liver cirrhosis patients. This study aimed to determine its relationship; thus, efforts can be made to prevent HE incidence in liver cirrhosis patients better.

\section{METHOD}

This study used an observational study design with a retrospective cohort approach. The research subjects were adult patients with liver cirrhosis who came to the outpatient clinic and emergency department of dr. Saiful
Anwar Hospital Malang. The research was conducted at the gastro-hepatology clinic and inpatient installation I of dr. Saiful Anwar Hospital Malang from 1 August 2019 to 31 July 2020. The independent variable measured were ascites and total lymphocyte count, while the dependent variable was the $\mathrm{HE}$ incidence.

Baseline data were collected by interviews on the history of the liver cirrhosis diagnosis, etiology, and complications of $\mathrm{HE}$ experienced; medical records study regarding laboratory results and data supporting the diagnosis of liver cirrhosis; and physical examination to assess the presence of ascites. Data were presented as mean \pm standard deviation or percentage. Parametric data were tested for normality to determine the data distribution. Furthermore, logistic multiple regression tests with enter method were performed for multivariate analysis and finding out the relationship between variables using SPSS 25 . The relationship between variables was considered statistically significant if $p$-value $<0.05$ and confidence interval (CI) 95\%. Determinant factor in this study was $\mathrm{HE}$ occurence.

\section{RESULTS}

Of the 78 subjects included, the mean age of liver cirrhosis patients with or without hepatic encephalopathy was not significantly different. The proportion of male patients in the group with $\mathrm{HE}$ and non-HE outcomes were 72.72 percent and 73.21 percent, respectively. In both groups, the number of study subjects with liver cirrhosis disease duration of fewer than two years was more significant than those of more or equal to two years. The most common etiology for cirrhosis, both in liver cirrhosis patients with $\mathrm{HE}$ and non-HE, is hepatitis $\mathrm{B}$.

Table 1. Baseline characteristic of study subjects

\begin{tabular}{lrrr}
\hline Baseline characteristic & $\begin{array}{c}\text { Hepatic } \\
\text { Encephalopathy }\end{array}$ & $\begin{array}{c}\text { Non-Hepatic } \\
\text { Encephalopathy }\end{array}$ & $\mathbf{p}$ \\
\hline Age (year) & $54.27 \boxplus 2.38$ & $53.16 \pm 0.38$ & 0.716 \\
Male & $16(72.72 \%)$ & $41(73.21 \%)$ & 0.965 \\
Disease duration <2 & $18(81.8 \%)$ & $35(62.5 \%)$ & 0.108 \\
years & & & \\
Etiology & $12(54.54 \%)$ & $42(75 \%)$ & 0.083 \\
$\quad$ Hepatitis B & $7(31.81 \%)$ & $9(16.07 \%)$ & 0.128 \\
$\quad$ Hepatitis C & $3(13.63 \%)$ & $5(8.93 \%)$ & 0.540 \\
\hline Others & & & \\
\hline
\end{tabular}

Before analyzing the correlation between variables, a normality test was carried out to determine the distribution of total lymphocyte count (TLC) data, which is parametric data. The analysis results using the Sapiro-Wilk test found normal TLC data distribution, so correlation analysis among variables was continued with multiple logistic regression tests.

The results (Table 2 ) show that ascites correlate with the incidence of $\mathrm{HE}$ with an odds ratio of 5.108 and a confidence interval of 1.36-19.25. Meanwhile, total lymphocyte count does not have a significant correlation with the incidence of $\mathrm{HE}$. 
Table 2. Correlation between Ascites and TLC with HE incidence

\begin{tabular}{lccccc}
\hline Variable & HE & Non-HE & OR & $\mathbf{9 5 \% C l}$ & $\mathbf{p}$ \\
\hline Ascites & $19(86.36 \%)$ & $31(55.35 \%)$ & 5.108 & $1.36-19.25$ & 0.016 \\
TLC & $1035 \pm 502$ & $1117 \pm 526$ & 0.751 & $0.31-1.84$ & 0,531 \\
\hline
\end{tabular}

\section{DISCUSSION}

Liver cirrhosis is one of the leading causes of death worldwide. The increasing prevalence of liver cirrhosis is associated with an increased burden of the risk factor, such as hepatitis B, hepatitis $C$, and alcohol abuse. Unlike the most common cause of liver cirrhosis in developed countries, which is due to alcohol abuse, the most common cause in developing countries, such as Indonesia, is hepatitis B infection (14). A study by Sajja et al. in 2014 on the demographic characteristics of cirrhosis patients with various causes found that the number of male patients was higher than that of female, and the largest proportion was on over 40 years age group (15). Patient characteristics and the most common cause of hepatitis B in the previous study were the same as the characteristics found in this study.

This study proves that ascites, which is a manifestation of portal hypertension, is associated with the incidence of $\mathrm{HE}$. These results are consistent with studies by Bohra et al. that HE occurs in patients with advanced cirrhosis, decompensation, and portal hypertension, and the most common precipitating factors are infection, gastrointestinal bleeding, constipation, non-adherence to medication, and electrolyte imbalance (16). A study by Tapper et al. in 2019 found that two factors which most strongly associated with HE were alcohol-related liver cirrhosis and the presence of portal hypertension (17).

The prevalence of HE was higher in the advanced liver disease who had experienced portal hypertension. Pathophysiologically, portal hypertension causes portosystemic shunting, thereby increasing ammonia in the systemic circulation, which then crosses the bloodbrain barrier and triggers various reactions that end in the manifestation of HE. One of the other manifestations of portal hypertension is ascites, one of the most common clinical manifestations of cirrhosis patients.

The discovery of a relationship between ascites and $\mathrm{HE}$

\section{REFERENCES}

1. Tranah TH, Paolino A, and Shawcross DL. Pathophysiological Mechanisms of Hepatic Encephalopathy. Clinical Liver Disease A Multimedia Review Journal. 20155; 5(3): 59-63.

2. Nurdjanah S. Sirosis Hati. In: Sudoyo AW, Setiyohadi B, Alwi I, Simadibrata KM, Setiati S (Eds). Buku Ajar Ilmu Penyakit Dalam. 6th edition. Jakarta: Internal Publishing; 2014: pp.1980-1985.

3. Elwir S and Rahimi RS. Hepatic Encephalopathy: An Update on the Pathophysiology and Therapeutic Options. Journal of Clinical and Translational Hepatology. 2017; 5(2): 142-151.

4. Montagnese S and Bajaj JS. Impact of Hepatic Encephalopathy in Cirrhosis on Quality-of-Life can offer benefits in HE prevention efforts. Because of the higher risk of $\mathrm{HE}$ in ascites patients, management of cirrhotic patients with ascites who have not experienced HE complications should be more aggressive. Besides, the prevention of $\mathrm{HE}$ precipitation factor can be done more optimally.

Lymphopenia is an indicator of malnutrition and poor immune response in patients with chronic liver disease. A study by Zhang et al. found that the lymphocyte values were lower, and the neutrophil-lymphocyte ratio was higher in cirrhotic patients. One explanation for lymphopenia in the circulation is that many lymphocytes are localized in the liver to play a role in the necroinflammatory process (18). Immune dysfunction in liver cirrhosis triggers a systemic inflammatory response, which is a factor in the pathophysiology of HE. This association is the basis for the hypothesis of the relationship between immune dysfunction as represented by TLC, although in this study the hypothesis was not proven.

Several studies have been conducted to analyze the correlation of systemic inflammatory response with $\mathrm{HE}$ incidence. A study by Shawcross et al. in 2004 concluded that inflammation and its mediators play an important role in modulating the effect of ammonia in liver disease (19). Another study by Odeh et al. in 2005 proved that there is a correlation between tumor necrosis factor and the pathogenesis of HE (20). This explains that the systemic inflammatory response is still thought to be related to the incidence of HE. However, due to many factors that play a role in the systemic inflammatory response, TLC alone as a parameter of immune dysfunction may not be the sole indicator that can be examined. In addition, another limitation in this study is that there is no information about the precipitating factor of HE. TLC or other immune dysfunction parameters may have different results in $\mathrm{HE}$ patients with infection as a precipitating factor.

Thus, this study concluded that ascites would increase the incidence of $\mathrm{HE}$ in liver cirrhosis 5 times higher than without ascites. Meanwhile, there was no relationship between TLC as a parameter of immune dysfunction and the incidence of $\mathrm{HE}$ in liver cirrhosis patients.

\section{CONFLICT OF INTEREST}

The authors declare that they have no conflict of interest.

5. Michalska IC, Szczepanek M, Slowik A, and Mach T. Pathogenesis of Hepatic Encephalopathy. Gastroenterology Research and Practice. 2012; 2012:1-7.

6. Ferenci P. Hepatic Encephalopathy. Gastroenterology Report. 2017; 5(2): 138-147.

7. Frederick, RT. Current Concepts in the Pathophysiology and Management of Hepatic Encephalopathy. Gastroenterology and Hepatology. 2011; 7(4): 222-233.

8. European Association for the Study of the Liver. EASL Clinical Practice Guidelines on the Management of Ascites, Spontaneous Bacterial Peritonitis, and Hepatorenal Syndrome in Cirrhosis. Journal of 
Hepatology. 2010; 53(3): 397-401.

9. Mustapha SK. Cirrhotic Ascites: A Review of Pathophysiology and Management. Nigerian Journal of Gastroenterology and Hepatology. 2020; 12(1): 1-8.

10. Albillos A, Lario M, and Alvarez-Mon M. CirrhosisAssociated Immune Dysfunction: Distinctive Features and Clinical Relevance. Journal of Hepatology. 2014; 61(6): 1385-1396.

11. Liaskou E and Hirschfield GM. Cirrhosis-Associated Immune Dysfunction: Novel Insights in Impaired Adaptive Immunity. EBioMedicine. 2019; 50: 3-4.

12. Bogdanos DP, Gao B, and Gershwin ME. Liver Immunology. Comprehensive Physiology. 2013; 3(2): 567-598.

13. Noor MT and Manoria, P. Immune Dysfunction in Cirrhosis. Journal of Clinical and Translational Hepatology. 2017; 5(1): 50-58.

14. Wong MCS and Huang J. The Growing Burden of Liver Cirrhosis: Implications for Preventive Measures. Hepatology International. 2018; 12(3): 201-203.

15. Sajja KC, Mohan DP, and Rockey DC. Age and Ethnicity in Cirrhosis. Journal of Investigative Medicine. 2014;62(7): 920-926.
16. Bohra A, Worland T, Hui S, Terbah R, Farrel, A, and Robertson M. Prognostic Significance of Hepatic Encephalopathy in Patients with Cirrhosis Treated with Current Standards of Care. World Journal of Gastroenterology. 2020; 26(18): 2221-2231.

17. Tapper EB, Henderson JB, Parikh ND, loannou GN, and Lok AS. Incidence of and Risk Factors for Hepatic Encephalopathy in a Population-Based Cohort of Americans with Cirrhosis. Hepatology Communications. 2019; 3(11): 1510-1519.

18. Zhang H, Sun Q, Mao W, Fan J, and Ye B. Neutrophilto-Lymphocyte Ratio Predicts Early Mortality in Patients with HBV-Related Decompensated Cirrhosis. Gastroenterology Research and Practice. 2016; 2016: 1-5.

19. Shawcross DL, Davies NA, Williams R, and Jalan R. Systemic Inflammatory Response Exacerbates the Neuropsychological Effects of Induced Hyperammonemia in Cirrhosis. Journal of Hepatology. 2004; 40(2): 247-254.

20. Odeh M, Sabo E, Srugo I, and Oliven A. Relationship between Tumor Necrosis Factor-Alpha and Ammonia in Patients with Hepatic Encephalopathy Due to Chronic Liver Failure. Annals of Medicine. 2005; 37(8): 603-612. 